\title{
The Power of Group Investigation Model on Student Critical Thinking, Attitude, and Character in Learning Physics
}

\author{
I Wayan Santyasa \\ Physics Education Department \\ Universitas Pendidikan Ganesha \\ Singaraja, Indonesia \\ santya@undiksha.ac.id / santyasa@yahoo.com
}

\author{
I Wayan Sukra Warpala \\ Biology Department \\ Universitas Pendidikan Ganesha \\ Singaraja, Indonesia \\ yansukra@undiksha.ac.id
}

\author{
I Komang Sudarma \\ Educational Technology Department \\ Universitas Pendidikan Ganesha \\ Singaraja, Bali, Indonesia \\ komangsudarma@undiksha.ac.id
}

\begin{abstract}
Learning physics in senior high school by using a teacher-centered teaching habit must be changed. It has to empower the investigated-based collaboration. This quasi experimental study aims to analyze the effect of group investigation (GI) model compared to direct instruction (DI) model on critical thinking skills, social and spiritual attitudes, and students character. This experimental study employed a posttest only control group design. The population was 15 classes or 488 students of class X MIPA from three SMAs in Klungkung regency. The research sample was chosen by random assignment technique, and 2 classes were determined in each school, so there were 6 classes (194 students, or $39.8 \%$ of the population), 3 classes using GI and 3 other classes using DI. The study was conducted for 5 weeks each 3 hours on energy and momentum learning material. Critical thinking skills were collected by using 15 essay test items. Students social and spiritual attitudes and their character were collected by using questionnaire, every 30 items, 30 items, and 18 item respectively. Data were analyzed by one way MANOVA. The results show that GI model was better than DI model for achieving students critical thinking, social attitudes, spiritual attitudes, and their character in learning physics in the senior high schools.
\end{abstract}

Keywords-Collaborative investigation, critical thinking, social attitudes, spiritual attitudes, character

\section{INTRODUCTION}

Physics learning has still kept problems that have not been resolved. Students mainly experience these problems in the context of mastery of physical concepts and adequate learning achievement. Mastery of physics concepts and student achievement in class X high school tends to be low [1]. One of the internal factors as a cause is that high school students often view physics as a difficult and very abstract lesson [2, 3]. External factors which also trigger the low mastery of physics concepts and the low achievement of learning physics are caused by learning implemented in physics learning tends to be teacher-centered [1][2].

One of the student achievements in school is critical thinking skills in learning physics. The effectiveness of teacher-centered learning is one factor that has not been optimal in achieving students' critical thinking skills. The results of the previous studies have revealed that students' critical thinking skills are still lack [4][5][6][7][8]. Students' critical thinking skills are the direct impact of learning applied by the teacher. If the learning designed by the teacher tends to be centered on students, the opportunity for students to move in learning physics will be reduced. Lack of students' activity in learning will undoubtedly dwarf their potential thinking, including critical thinking skills students will become weak in growth. In fact, students' critical thinking skills are needed in facing the challenges of the 21st century [9][10]. They highlight that critical thinking is an important part that students must build in schools in the 21 st century. Critical thinking skill is one of the skills that can be relied upon in facing rapid changes in all lines of society [11] and in facing all the demands of the times [12]. Therefore, teacher-centered learning must be considered not to be applied in learning.

One of teacher-centered learning programs is direct instruction (DI). DI program in schools is generally carried out with linearly programmed learning models. The teacher follows step by step, the lesson-by-lesson approach that follows the sequence of skills that have been determined and then given to students. The prescribed approach to teaching is fast and linear which aims to maximize timeliness in carrying out tasks and positively reinforce student behavior [13]. The teacher provides rigorous training by following the teacher's guidebook. The teacher focuses more on efforts to present curriculum material. Material presentations are followed by assigning assignments, giving tests, and conducting assessments that are in line with predetermined learning goals. 
Evaluation results are followed by feedback to change behavior, grouping abilities, and emphasis on academic skills. Because the focus of learning is more on academic achievement, the impact of accompaniment is often excluded from learning. Character development, social attitudes, and spiritual attitudes of students are no longer an important part of learning. As a result, students often show characters that are not good, low social attitudes, as well as their spiritual attitudes do not experience development in a better direction.

Students from the past to the present generation often carry out some destructive actions, bad behavior, substance abuse, stealing, and other crimes [14]. According to them, the phenomenon shows that the character of students is still bad, so it needs to be improved in a better direction. These bad characters make educators, teachers, parents, religious organizations, and the government are worried. Another fact also states that students' social attitudes at school are still low, so it needs to be improved in educational praxis [15][16). As an impact of accompanying learning, students' spiritual attitudes also need to be improved in learning in school [17].

Based on the facts described above, and given the importance of developing critical thinking skills, character, social attitudes, and spiritual attitudes of students in learning physics at school, naturally DI implementation cannot be maintained anymore. Physics learning must apply a new paradigm of learning that has the potential to accommodate the efforts to develop critical thinking skills, character, social attitudes, and spiritual attitudes of students. In other words, DI must be abandoned and must begin to apply the student centered learning (SCL) approach. One of the derivatives is the group investigation (GI) model. The GI model has proven its superiority in learning various fields of science. In writing learning in elementary school, the GI model turns out to be the most superior compared to the accelerated learning team also superior to the role playing model [18]. In physics learning, the GI model is superior to conventional models in achieving physics learning achievement in high school [19]. In learning physics in high school, it has also been proven that the GI model is superior to the conventional model in achieving conceptual understanding [20]. The GI model has also proven its advantage in speaking learning on English subjects for high school students [21]. The GI model has also been tested for its superiority in physics learning, motion and style material for first semester students, compared to the learning together model, which is superior to the DI model in achieving learning achievement [3]. In learning mathematics in junior high school, the GI model was tested superior to conventional models in achieving learning achievement [22]. In learning English in high school, the GI model was proven to improve speaking skills for students [23]. In learning the physics of the concepts of temperature and heat, the GI model is superior to conventional learning in achieving conceptual understanding and science process skills [1]. In class XI high school physics learning it has also been proven that the GI model is superior to the Jigsaw model in achieving learning achievement [2]. The GI model has also been shown to improve student achievement in vocational schools [24].

\section{METHOD}

This study used a quasi-experimental method with a posttest control group design involving three state senior high schools in Klungkung district in the even semester of the school year 2017/2018. These schools were SMA Negeri 1 Semarapura, SMA Negeri 2 Semarapura, and SMA Negeri 1 Banjarangkan. This study involved class $X$ students in learning physics. The total number of classes were 15 classes consisting of 5 classes or 183 students of SMA Negeri 1 Semarapura, 7 classes or 228 students of SMA Negeri 2 Semarapura, and 3 classes or 77 students of SMA 1 Banjarangkan. The sample was selected randomly to determine 2 classes in each school as a class sample. The total sample was 6 classes (194 students or 39.8\% of the total population) which were divided into two groups, namely 3 classes (97 students) subject to GI treatment and 3 classes (97 students) subject to DI treatment. This experiment was conducted by physics teachers in each high school. Previously, they were given 5 days of training on physics learning using GI models and DI models. Physics subject matters which is the object of this research were the materials of effort, energy, impulse, and momentum. The implementation of this treatment adapted to the subject matter and the time allocation available on K-13. The treatment procedures in the GI and DI groups were presented in Table 1 .

TABLE I. DESCRIPTION OF LEARNING STEPS AND STUDENTS ACTIVITIES IN THE GI AND DI MODELS

\begin{tabular}{|c|c|c|c|}
\hline \multicolumn{2}{|c|}{ GI Model } & \multicolumn{2}{|c|}{ DI Model } \\
\hline $\begin{array}{l}\text { Learning } \\
\text { Steps }\end{array}$ & Learning activities & $\begin{array}{l}\text { Learning } \\
\text { Steps }\end{array}$ & $\begin{array}{l}\text { Learning } \\
\text { activities }\end{array}$ \\
\hline $\begin{array}{l}\text { Identify } \\
\text { topics and } \\
\text { form study } \\
\text { groups }\end{array}$ & $\begin{array}{l}\text { Students study and } \\
\text { choose topics that } \\
\text { are relevant to } \\
\text { themselves and } \\
\text { their groups }\end{array}$ & $\begin{array}{l}\text { motivating } \\
\text { students }\end{array}$ & $\begin{array}{l}\text { The teacher } \\
\text { motivates } \\
\text { students } \\
\text { regarding the } \\
\text { subject matter } \\
\text { discussed }\end{array}$ \\
\hline $\begin{array}{l}\text { Plan learning } \\
\text { tasks }\end{array}$ & $\begin{array}{l}\text { Students in groups } \\
\text { form plans for } \\
\text { investigations } \\
\text { according to the } \\
\text { roles of each group } \\
\text { to achieve group } \\
\text { goals }\end{array}$ & $\begin{array}{l}\text { delivering } \\
\text { lesson } \\
\text { material }\end{array}$ & $\begin{array}{l}\text { The teacher } \\
\text { presents the } \\
\text { subject matter } \\
\text { followed }\end{array}$ \\
\hline $\begin{array}{l}\text { Carry out an } \\
\text { investigation }\end{array}$ & $\begin{array}{l}\text { Students seek } \\
\text { information, } \\
\text { analyze data, and } \\
\text { draw conclusions, } \\
\text { exchange ideas, } \\
\text { discuss, clarify, and } \\
\text { synthesize ideas }\end{array}$ & $\begin{array}{l}\text { forming } \\
\text { groups } \\
\text { students }\end{array}$ & $\begin{array}{l}\text { The teacher } \\
\text { instructs } \\
\text { students to } \\
\text { form groups of } \\
3-5 \text { people and } \\
\text { share group } \\
\text { assignments }\end{array}$ \\
\hline $\begin{array}{l}\text { Prepare final } \\
\text { report }\end{array}$ & 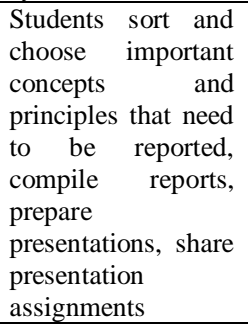 & $\begin{array}{l}\text { students } \\
\text { learning } \\
\text { groups }\end{array}$ & $\begin{array}{l}\text { Students work } \\
\text { on assignments } \\
\text { given by the } \\
\text { teacher in each } \\
\text { group and } \\
\text { formulate the } \\
\text { report on the } \\
\text { results of the } \\
\text { discussion }\end{array}$ \\
\hline $\begin{array}{l}\text { Present the } \\
\text { final report }\end{array}$ & $\begin{array}{l}\text { Students make } \\
\text { presentations } \\
\text { alternately } \\
\text { according to their }\end{array}$ & $\begin{array}{l}\text { students } \\
\text { reporting the } \\
\text { results of the } \\
\text { discussion }\end{array}$ & $\begin{array}{l}\text { The teacher } \\
\text { appoints the } \\
\text { group in turn to } \\
\text { report the }\end{array}$ \\
\hline
\end{tabular}




\begin{tabular}{|c|l|l|l|}
\hline $\begin{array}{c}\text { Gearning } \\
\text { Steps }\end{array}$ & Learning activities & \multicolumn{1}{|c|}{$\begin{array}{c}\text { Learning } \\
\text { Steps }\end{array}$} & $\begin{array}{c}\text { Learning } \\
\text { activities }\end{array}$ \\
\hline \multirow{2}{*}{$\begin{array}{l}\text { assignments in } \\
\text { groups and answer } \\
\text { questions that arise }\end{array}$} & $\begin{array}{l}\text { results of the } \\
\text { discussion }\end{array}$ \\
& $\begin{array}{l}\text { Students receive } \\
\text { feedback from the } \\
\text { teacher, conduct } \\
\text { self-assessments, } \\
\text { and work on } \\
\text { individual } \\
\text { evaluations }\end{array}$ & $\begin{array}{l}\text { teachers } \\
\text { student } \\
\text { reports }\end{array}$ & $\begin{array}{l}\text { The teacher } \\
\text { assesses } \\
\text { student } \\
\text { discussion } \\
\text { reports and } \\
\text { gives quizzes }\end{array}$ \\
\hline
\end{tabular}

The treatment as in Table 1 was carried out for 5 meetings. At the 6th meeting, students in both groups were given a critical thinking test in learning physics with an allocation of 90 minutes. Over the next 30 minutes, students answer social attitudes, spiritual attitudes, and character questionnaires.

\section{- Critical thinking tests}

Critical thinking tests were arranged in the form of an essay with each item's rubric using a 0-5 scale, while the questionnaire uses a 1-4 scale. The trial results set 15 items of the critical thinking instrument used in collecting data. The different power index (DPI) of this instrument moves from 0.20 to 0.62 , their item difficulty index (IDI) moves from 0.22 to 0.84 , and item-total correlation coefficients $\left(\mathrm{r}_{\mathrm{xy}}\right)$ moves from 0.44 to 0.88 . Cronbach's alpha coefficient of 12 test items which stated the reliability of critical thinking instruments were 0.899 with very high qualifications.

\section{- Social attitudes questionnaire}

The social attitude consisted of 4 dimensions, namely 1) the attitude of organizing groups, 2) the attitude of negotiating solutions, 3) the attitude of maintaining personal relationships, and 4) attitude in carrying out social analysis. The 4 dimensions of social attitudes are translated into 30 items of social attitude instruments. Each item uses a Likert Scale by removing neutral elements so that the scale is degraded 1-4. The results of the trial on 291 subjects showed that the correlation coefficient of the total item of social attitude questionnaire moves from 0.36 to 0.60 with 30 item reliability is 0.91 with very high qualifications.

\section{- Spiritual attitude questionnaire}

Spiritual attitude uses eight dimensions adapted from subscales and spiritual attitudes and involvement lists (SAIL) items consist of 1) Meaningfulness, 2) Trust, 3) Acceptance, 4) Awareness in the present, 5) Caring for others, 6) Connectedness with nature, 7) Transcendent experiences, 8) Spiritual activities. The eight dimensions of spiritual attitudes are differentiated into 30 items. Each item uses a Likert Scale by removing neutral elements so that the scale becomes 1-4. The results of trials on subjects as many as 294 people showed that the correlation coefficient of the total item of spiritual attitude questionnaire move from 0.30 to 0.61 with 30 item reliability is 0.84 with high qualifications.

\section{- Character Questionnaire}

The character of the student consists of 10 dimensions [37], namely 1) the love of God and all of his creation, 2) independence and responsibility, 3) honesty/trust, 4) diplomatic, 5) respect and polite, 6) generous, like helping each other and collaboration, 7) confidence and hard worker, 8) leadership and justice, 9) good and humble, 10) tolerance, peace, and unity. Student character data was collected by questionnaire, consisting of 18 statement items, each equipped with four degradation options using a scale of 0-4. Description of each scale of degradation $0-4$ is $0=$ disagree, $1=$ less agree, 3 = agree, 4 = strongly agree. The correlation coefficient of Pearson Product moment item-total moves from $r=0.36$ to $r=$ 0.72 . The reliability index was determined by the Alpha Cronbach coefficient $\alpha=0.80$.

\section{RESULTS AND DISCUSSION}

\section{A. Descriptive Results}

The results of this descriptive analysis present the influence of GI compared to DI in achieving the 4 dependent variables, namely critical thinking skills, social attitudes, spiritual attitudes, and the student's character of SMA Negeri 1 Semarapura, SMA Negeri 2 Semarapura, and SMAN 1 Banjarangkan. The results of the analysis are presented in Table 2.

TABLE II. THE SUMMARY OF THE RESULTS OF THE DESCRIPTIVE ANALYSIS OF CRITICAL THINKING SKILLS, SOCIAL ATTITUDES, SPIRITUAL ATTITUDES, AND THE CHARACTER OF THE STUDENTS.

\begin{tabular}{|l|l|l|l|l|}
\hline $\begin{array}{c}\text { Dependent } \\
\text { Variable }\end{array}$ & Model & \multicolumn{1}{|c|}{ Mean } & \multicolumn{1}{|c|}{ SD } & N \\
\hline Critical & GI & 30.6907 & 5.77415 & 97 \\
\hline & DI & 21.0412 & 6.29305 & 97 \\
\hline Social & GI & 100.2577 & 9.06145 & 97 \\
\hline & DI & 94.4433 & 7.01185 & 97 \\
\hline Spiritual & GI & 97.5670 & 10.49395 & 97 \\
\hline & DI & 89.8866 & 5.82358 & 97 \\
\hline Character & GI & 59.7423 & 5.88833 & 97 \\
\hline & DI & 57.8351 & 4.73392 & 97 \\
\hline
\end{tabular}

The results of the descriptive analysis in Table 2 show that the critical thinking skills, social attitudes, spiritual attitudes, and character of students are higher achieved by students who study with the GI model than the DI model.

Test assumptions carried out include the normality test of data distribution using Kolmogorov-Smirnov and ShapiroWilk statistics, Box's Test of Equality of Covariance Matrices, and Levene's Test of Equality of Error Variances. A summary of the test results is presented in Table 3 , Table 4 , and Table 5.

TABLE III. SUMMARY OF THE RESULTS OF THE NORMALITY TEST OF THE DISTRIBUTION OF EXPERIMENTAL DATA

\begin{tabular}{|l|l|c|c|c|c|c|}
\hline \multirow{2}{*}{\multicolumn{1}{c}{ Source }} & \multicolumn{2}{|c|}{ Kolmogorov-Smirnov ${ }^{\mathbf{a}}$} & \multicolumn{3}{c|}{ Shapiro-Wilk } \\
\cline { 2 - 8 } Statistic & $\boldsymbol{d} \boldsymbol{f}$ & Sig. & Statistic & $\boldsymbol{d f}$ & Sig. \\
\hline Critical in GI & 0.110 & 97 & 0.096 & 0.964 & 97 & 0.089 \\
\hline Social in GI & 0.061 & 97 & 0.200 & 0.986 & 97 & 0.370 \\
\hline Spiritual in GI & 0.066 & 97 & 0.200 & 0.986 & 97 & 0.411 \\
\hline Character in GI & 0.074 & 97 & 0.200 & 0.979 & 97 & 0.114 \\
\hline Critical in DI & 0.128 & 97 & 0.101 & 0.933 & 97 & 0.115 \\
\hline Social in DI & 0.121 & 97 & 0.125 & 0.931 & 97 & 0.165 \\
\hline Spiritual in DI & 0.100 & 97 & 0.117 & 0.971 & 97 & 0.128 \\
\hline Character in DI & 0.224 & 97 & 0.088 & 0.885 & 97 & 0.092 \\
\hline
\end{tabular}


Based on the results of the normality test in Table 3, it appears that the Kolmogorov-Smirnov and Shapiro-Wilk statistical values on the four dependent variables show the numbers of significance that are greater than 0.05 . So the data of critical thinking skills, social attitudes, spiritual attitudes, and character of students are normally distributed.

TABLE IV. BOX'S TEST OF EQUALITY OF COVARIANCE MATRICES

\begin{tabular}{|l|l|}
\hline \multicolumn{1}{|c|}{ Box's M } & \multicolumn{1}{c|}{$\mathbf{5 5 . 3 5 5}$} \\
\hline F & 1.411 \\
\hline df1 & 10 \\
\hline df2 & 176242.231 \\
\hline Sig. & 0.217 \\
\hline
\end{tabular}

The results of Box's Test of Equality of Covariance Matrices as shown in Table 4, that the Box'M statistic value is $\mathrm{F}=1.411$ with a significance number of $\operatorname{sig}=0.217$ which is greater than 0.05 significance. It shows that the covariance matrices of the dependent variable are homogeneous. The results of this test are the assumptions of the Multivariate Analysis of Covariance.

As an assumption, Tests of Between-Subjects Effects requires Levene's Test of Equality of Error Variances. A summary of the test results is presented in Table 5 .

TABLE V. LEVENE'S TEST OF EQUALITY OF ERROR VARIANCES

\begin{tabular}{|l|l|l|l|l|}
\hline Dependent Variables & \multicolumn{1}{|c|}{ F } & df1 & df2 & Sig. \\
\hline Critical & 0.385 & 1 & 192 & 0.536 \\
\hline Social & 2.860 & 1 & 192 & 0.116 \\
\hline Spiritual & 2.502 & 1 & 192 & 0.096 \\
\hline Character & 2.521 & 1 & 192 & 0.065 \\
\hline
\end{tabular}

Table 5 shows that the Levene statistics on all dependent variables have a significance number greater than 0.05 . Therefore, the fourth variant of the dependent variable from the two GI and DI treatment groups was homogeneous. Based on the analysis that MANOVA assumptions have been fulfilled, Table 6 shows the Multivariate Analysis of Covariance.

TABLE VI. Multivariate ANALYSIS OF COVARIANCE

\begin{tabular}{|l|l|l|l|c|}
\hline \multicolumn{1}{|c|}{ Statistic } & \multicolumn{1}{|c|}{ F } & $\begin{array}{c}\text { Hypothesis } \\
\text { df }\end{array}$ & Error df & Sig. \\
\hline Pillai's Trace & 40.058 & 4.000 & 189.000 & $\mathbf{0 . 0 0 0}$ \\
\hline Wilks' Lambda & 40.058 & 4.000 & 189.000 & 0.000 \\
\hline Hotelling's Trace & 40.058 & 4.000 & 189.000 & 0.000 \\
\hline $\begin{array}{l}\text { Roy's Largest } \\
\text { Root }\end{array}$ & 40.058 & 4.000 & 189.000 & 0.000 \\
\hline
\end{tabular}

Based on Table 6, it appears that the Pillai's Trace statistics, Wilks' Lambda, Hotelling's Trace, and Roy's Largest Root are $F=40,058$ with a significance number of sig $=0.001$ which is smaller than sig $=0.05$. Thus, compatible with the four dependent variables showed a significant difference between GI and DI treatment. These results provide clues that the need for Tests of Between-Subjects Effects as presented in Table 7.
TABLE VII. TESTS OF BeTWEEN-SUBJECTS EFFECTS

\begin{tabular}{|l|l|l|l|l|l|}
\hline \multicolumn{1}{|c|}{ DV } & $\begin{array}{c}\text { Type III Sum } \\
\text { of Squares }\end{array}$ & df & $\begin{array}{c}\text { Mean } \\
\text { Square }\end{array}$ & \multicolumn{1}{c|}{ F } & Sig. \\
\hline Critical & 4515.959 & 1 & 4515.959 & 123.821 & 0.000 \\
\hline Social & 1639.670 & 1 & 1639.670 & 24.981 & 0.000 \\
\hline Spiritual & 2860.954 & 1 & 2860.954 & 39.725 & 0.000 \\
\hline Character & 176.418 & 1 & 176.418 & 6.181 & 0.014 \\
\hline
\end{tabular}

Table 7 shows that separately the four dependent variables differed significantly between the results of GI and DI treatments. Based on Table 2, GI treatment was superior in achieving the four dependent variables, namely critical thinking ability $(\mathrm{M}=30.69 ; \mathrm{SD}=5.77)$ students compared to DI treatment $(M=21.04 ; S D=6.29)$; social attitudes on the GI, $\mathrm{M}=100.26 ; \mathrm{SD}=9.06$ and in $\mathrm{DI}, \mathrm{M}=94.44 ; \mathrm{SD}=7.01$; spiritual attitude on $\mathrm{GI}, \mathrm{M}=97.57$; $\mathrm{SD}=10.49$ and in $\mathrm{DI}, \mathrm{M}=$ 89.89; $\mathrm{SD}=5.81$; and student character on $\mathrm{GI}, \mathrm{M}=59.74$; $\mathrm{SD}$ $=5.89$ and in $\mathrm{DI}, \mathrm{M}=57.83 ; \mathrm{SD}=4.73$.

\section{B. Discussion}

The GI model as one of the SCL models is superior to the DI model in achieving critical thinking skills, social attitudes, spiritual attitudes, and good character development for students in physics learning. The results of this study are in accordance with previous studies [1, 2, 3, 19, 20, 25, 26]. Thus, the GI model is a learning model that is effective in improving student physics learning achievement compared to the DI learning model.

The superiority of the GI model is because the GI model is one of the innovative learning models that applies the cooperative approach and investigation in the learning process. The GI model provides learning activities by providing opportunities for students to conduct group investigations related to physical problems related to contextual learning material so that learning is more studentcentered. The GI model can facilitate students through investigative and discussion activities to determine and decide on alternative solutions that are considered the best so that they can help students develop thinking skills, problem solving skills, and intellectual skills in the learning process. Thus mastery of learning material will increase and also lead to increasing student learning achievement [19].

In physics learning, it was found that the GI model was more effective than the teacher centered learning model in achieving academic achievement in motion and style learning [3]. The GI model is one of the student centered learning (SCL) models. In recent years, studies related to physics show that teacher centered learning is not enough to educate students, and therefore, students learn physics superficially [3]. The implementation of learning in the GI model which is part of SCL actively involves students in learning and independent learning and provides permanent learning. The main purpose of this GI application is to give responsibility to students, their learning, and interactions with one another. Learning that occurs in the GI model provides an atmosphere of learning to listen to each other as peer age groups of students who can be fun and interesting to them, and this type of learning activity motivates them [3]. Thus, students share their opinions with other students in different groups, improve their shortcomings together and learn about different things 
that are very intensive involving high-level thinking skills and deep-based collaborative abilities and beliefs. These competencies are the fundament for students in developing their attitudes, including good social attitudes, good character, and good spiritual attitudes. It is the basis that in this study it was proven that social attitudes, spiritual attitudes, and character of students with better quality could be achieved by students studying with the GI model compared to DI models.

In research that uses material business objects, energy, impulses, and momentum, it is evident that the GI model is superior to DI in achieving critical thinking skills, social attitudes, spiritual attitudes, and the character of high school students. However, the treatment with GI models has not yet achieved the minimum completeness criteria. The results achieved this time was critical thinking skills $\mathrm{M}=30.69$ on a scale of 75 or $M=40.92$ on a scale of 100 , with fewer categories. These results are still far below the minimum completeness criteria, namely $\mathrm{M}=70$ on a scale of 100 . This is a challenge in the application of the next GI model, especially in efforts to achieve students' critical thinking skills in physics learning. The lack of achievement of the minimum completeness criteria for achieving students' critical thinking skills is because students are not familiar with this model so that 5 times the treatment has not shown optimal results. In other words, the application of the GI model should be continued on an ongoing basis, so students become accustomed to using the GI model. In this case, students may need more time to change their views on learning models [40].

Although the direct impact of learning especially in achieving critical thinking skills, GI model has not shown optimal results, but the accompanying impact of learning can be achieved namely social attitudes, spiritual attitudes, and student character, this model has shown results as expected. The accompanying impact of learning that can be achieved is, social attitudes $\mathrm{M}=100.26$ on a 120 scale or $\mathrm{M}=83.55$ on a scale of 100 , with a good category; his spiritual attitude is $\mathrm{M}=$ 97.57 on a scale of 120 or $\mathrm{M}=81.3$ on a scale of 100 , with a good category; and the character of students $\mathrm{M}=59.74$ on a scale of 72 or $M=82.97$ on a scale of 100 , with good categories. This is because, in the application of the GI model, students in the class are aware of their evolving academic, social, moral, and spiritual ways of life, namely established standards, and expectations. Teachers try to maintain a healthy academic, social, moral, and spiritual order. The GI model provides a pattern of negotiation of community-style meanings. The negotiation process of the meaning facilitates students to learn the academic domain of knowledge, and in the end, they are involved in solving social, moral, and spiritual problems [26, 27]. This potential is the basis that the GI model can reach categories both in social attitudes, spiritual attitudes, and character. This potential is not found in learning with DI models.

\section{CONCLUSION}

The GI model is more advanced than the DI model in achieving critical thinking, social attitudes, spiritual attitudes, and character of students in learning physics in class $\mathrm{X}$ of SMA Negeri 1 Semarapura, SMA Negeri 2 Semarapura, and SMA Negeri 1 Banjarangkan Klungkung in the subject matters of work, energy, impulse, and momentum. Critical thinking of students is the direct impact of the GI model, while social attitudes, spiritual attitudes, and student character are the indirect impacts. In the learning process, the GI model prioritizes the empowerment of students potential. The application of the GI should be able to be maintained and improved the quality of the process so that it can give a direct impact on students critical thinking to be optimal.

\section{ACKNOWLEDGMENTS}

This research was conducted collaboratively between a team of lecturers, students, and high school teachers. Therefore, on this occasion, I would like to thank my fellow lecturers, S2 Learning Technology students, and high school physics teachers involved in this study. Also, thank you to the DRPM Dikti who funded this research and to the LP2M Undiksha for the coordination and moral encouragement given to the team during this research on the advice, financial, and thought given. May God provide commensurate rewards.

\section{REFERENCES}

[1] S. H. Parinduri, M. Sirait, and R. A. Sani, "The effect of cooperative learning model type group investigation for student's conceptual knowledge and science process skills," IOSR Journal of Research \& Method in Education (IOSR-JRME), vol. 7, issue 4, ver. III, pp. 49-54, Jul - Aug 2017.

[2] K. A. Astiti, "The effect of group investigation learning model with brainstorming technique on students learning outcomes," 2018. [Online]. Available: https://doi.org/10.1051/shsconf/20184200122. [Accessed 20 09 2018].

[3] N. O. AKÇAY and K. DOYMUŞ, "The effects of group investigation and cooperative learning techniques applied in teaching force and motion subjects on students' academic achievements," Journal of Educational Sciences Research, vol. 2, no. 1, 109-123, June 2012.

[4] M. H. Asoodeh, M. B. Asoodeh and M. Zarepour, "The impact of student - centered learning on academic achievement and social skills. Procedia - Social and Behavioral Sciences," 2012. [Online]. Available: www.sciencedirect.com. [Accessed 1810 2018].

[5] N. M. Fuad, S. Zubaidah, S. Mahanal, and S. Endang, "Improving junior high schools critical thinking skills based on test three different models of learning," International Journal of Instruction. vol. 10, no. 1, pp. 101116, 2017.

[6] M. KARAKOÇ, "The significance of critical thinking ability in terms of education," International Journal of Humanities and Social Science, vol. 6, no. 7, pp. 81-84, 2016.

[7] W. Rajagukguk and E. Simanjuntak, "Problem-based mathematics teaching kits integrated with ICT to improve students' critical thinking ability in junior high school in Medan," Cakrawala Pendidikan, vol. 3, pp. 347-356, 2015.

[8] D. T. Tiruneh, M. D. Cock, A. G. Weldeslassie, J. Elen, and R. Janssen, "Measuring critical thinking in physics: Development and validation of a critical thinking test in electricity and magnetism," International Journal of Science and Math Education, vol.15, pp. 663-682, 2016.

[9] M. Barry, What skills will you need to succeed in the future? Phoenix Forward (online). Tempe, AZ, University of Phoenix, 2012.

[10] T. Wagner, "Overcoming the global achievement gap," 2010. [Online]. Available:

http://www.aypf.org/documents/Wagner\%20Slides\%20\%20global\%20a chievement\%20gap\%20brief\%205-10.pdf. [Accessed 20102018 ].

[11] S. C. Kong, "An experience of a three-year study on the development of critical thinking skills in flipped secondary classrooms with pedagogical and technological support. Elsevier, vol. 89, pp. 16-31, 2015. 
[12] B. Moeti, R. K. Mgawi, and W. T. S. Moalosi, "Critical thinking among post-graduate diploma in education students in higher education," Journal of Education and Learning. vol. 6, no. 2, 13-24, 2017.

[13] A. Luke, "On explicit and direct instruction. Australian Literacy Educator's Association. More area 'hot topics','2014. [Online]. Available www.alea.edu.au. [Accessed 1210 2018].

[14] A. Agboola and K. C. Tsai, "Bring character education into classroom. European,” Journal Of Educational Research, vol. 1, no. 2, pp. 163-170, 2012.

[15] Q. P. S. Law, H. C. F. So, and J. W. Y. Chung, "Effect of collaborative learning on enhancement of students' self-efficacy, social skills and knowledge towards mobile apps development," American Journal of Education Research, vol. 5, no. 1, pp. 25-29, 2017.

[16] G. Sammut, "Measuring Attitudes and Points of View: Social Judgment of Proposals for the Revision of Student Stipends in Higher Education," Psychology \& Society, vol. 5, no. 1, pp. 54-66, 2013.

[17] B. Bahmani, M. Ebrahimi, M. S. Seyadi, Z. Rahimi, and M. Naghiyaee, "The role of spiritual attitude in child-rearing in predicting the psychological hardiness of mothers with handicapped children," Iranian Rehabilitation Journal, vol. 13, no. 2, pp. 34-37, 2015.

[18] A. Pitoyo, H. J. Waluyo, S. Suwandi, and Andayani, "The effect of group investigation learning model, accelerated team and role playing on elementary school students writing skills viewed from cognitive style," Journal of Education and Practice, vol.5, no.1, pp. 21-29, 2014.

[19] E. Sari, "Pengaruh model pembelajaran kooperatif tipe group investigation terhadap hasil belajar fisika ditinjau dati kemampuan berpikir logis,” Jurnal Pendidikan Fisika. vol. 6, no. 1, pp. 27-32, 2017.
[20] F. Yuandini and Sahyar, "The effect of cooperative learning model type group investigation assisted flash media, scientific attitude on students conceptual knowledge," Journal of Education and Practice, vol.8, no.17, pp. 150-155, 2017.

[21] F. Ahsanah, "Group investigation: A cooperative learning method for the 10th-grade students in speaking english classroom," TELL Journal, vol. 3, no. 1, pp. 57-69, April 2015.

[22] D. Indarti, Mardiyana, and I. Pramudya, "Group investigation with scientific approach in mathematics learning," Journal of Physics: Conf. Series 983, 2018.

[23] Iswardati, "The implementation of group investigation to improve the students' speaking skill," Dinamika Ilmu, vol. 16, no. 2, pp. 245-261, 2016.

[24] S. Sangadji, "Implementation of cooperative learning with group investigation model to improve learning achievement of vocational school students in Indonesia," International Journal of Learning \& Development, vol. 6, no. 1, pp. 91-103, 2016.

[25] M. A. Pandi and S. Saehana, "Perbedaan hasil belajar fisika antara model pembelajaran kooperatif tipe group investigation (GI) dan model pembelajaran kooperatif tipe think pair square pada siswa kelas X SMA Negeri 9 Palu," Jurnal Pendidikan Fisika Tadulako (JPFT), vol. 3, no. 4, 58-63, 2016.

[26] I W. Santyasa, dan I N. P. Suwindra, "Pengembangan pemahaman konsep dan kemampuan pemecahan masalah fisika bagi siswa SMA dengan pemberdayaan model perubahan konseptual berseting investigas kelompok," Jurnal Penelitian dan Pengembangan Pendidikan, vol. 3, no. 1, pp. 1-16, Maret 2009. 